\title{
Walking on Thin Ice: The Perception of Tortious Liability Rules and the Effect on Altruistic Behaviour
}

\author{
Sebastian Peyer \& Rob Heywood*
}

\section{Introduction}

A desirable characteristic in any society is the willingness of individuals to help each other out from time to time. The majority of us would hope that in times of peril or distress, our fellow citizens would be inclined to offer their assistance. Equally, where the situation does not require intervention to help out in the face of imminent danger, there remains a significant societal benefit to be gained from those who voluntarily take it upon themselves to do something to help their fellow neighbour, or who endeavour to undertake a task with the desire of assisting members of the public in a broader context. ${ }^{1}$

In the same way we hear about altruistic acts, we also hear about situations in which onlookers have stood by and done nothing. ${ }^{2}$ If a bystander faced real and apparent danger in having to attempt a rescue, then the justification for refraining to act is perhaps more convincing than in, say, a situation where assistance could be provided without any real threat of harm to the helper. In the latter scenario, then, why might people choose not to act when their altruism may confer a benefit to someone else, without any significant burden to themselves? One potential reason is that people may be deterred from acting as a result of fear of increased exposure to legal liability should they intervene and should something subsequently go wrong. ${ }^{3}$ The sparse evidence that exists seems to suggest that a considerable proportion of those who have never volunteered are worried about liability when asked about the reasons for not volunteering. ${ }^{4}$

\footnotetext{
* Dr Sebastian Peyer, UEA Law School \& Centre for Competition Policy; Prof Rob Heywood, UEA Law School. The corresponding author can be reached at s.peyer@uea.ac.uk.

${ }^{1}$ The economic value of formal volunteering is estimate to be in the range of $£ 36$ to 40 billion. Natalie Low and others, 'Helping Out, A National Survey of Volunteering and Charitable Giving' (2007) http://www.ivr.org.uk/component/ivr/helping-out-a-national-survey-of-volunteering-and-charitable-giving 16.

${ }^{2}$ See, for example, recent news stories: https://www.theguardian.com/uk-news/2016/apr/19/police-seemedhesitant-water-help-river-lea-death-jack-susianta-inquest; https://www.theguardian.com/uknews/2015/nov/13/how-do-i-respond-racial-abuse-public-transport-onlookers-silent.

${ }^{3}$ Lord Hodgson of Astley Abbotts, 'Unshackling Good Neighbours' (May 2011) Report of the Task Force established to consider how to cut red tape for small charities, voluntary organisations and social enterprises 10 .

${ }^{4}$ Low and others (n 1) 68 .
} 
Concerns that those who rescue, help or volunteer may face liability have prompted the government to enact section 1 of the Compensation Act 2006 and, more recently, the Social Action, Responsibility and Heroism Act 2015 (SARAH). SARAH's objective is to allow the courts to consider the public benefits when assessing the breach of a duty, especially in the context of activities that confer a benefit to society. It supplements and arguably reiterates section 1 of the Compensation Act 2006. ${ }^{5}$ Anecdotal evidence and newspaper reporting may reinforce the perception that there is a legal liability issue concerning altruistic acts that, in turn, may discourage people to act. Occasionally, we encounter information that encourages people to conduct themselves in the exact opposite way to that which would be beneficial to society. 6

Our first proposition is that the tort of negligence treats volunteers and non-professional rescuers leniently and that there is a negligible risk of liability for altruistic acts. ${ }^{7}$ Secondly, we suggest that certain misperceptions about the risk of liability may deter potential volunteers from acting in the public interest. We argue that section 1 of the Compensation Act 2006 and SARAH are legislative attempts to provide an increased measure of protection for volunteers by ensuring that the threshold for legal culpability remains high. Thus, while there is a risk of liability, it will only be imposed in exceptional circumstances. If the aims of these legislative provisions are conveyed effectively beyond a mere legal audience, it may allow would-be volunteers to recognise that the chances of a successful court case being brought against them are remote. This may go some way towards redressing any overestimation that citizens may have about the chances of becoming the subject of a law suit, which, in turn, may lead to a greater inclination among members of society to act altruistically. ${ }^{8}$

We structure our paper as follows: in the first section, we define what we mean by altruistic acts in order to locate the main focus of our research. We highlight some of the problems that arise in a legal sense when someone with no duty to act does in fact decide to do so. ${ }^{9}$ In the next section, the analysis proceeds to converge on the theoretical legal difficulties

\footnotetext{
${ }^{5}$ Most commentators criticise section 1 and SARAH for being unnecessary and void of any purpose. For an assessment and overview of these legislative changes see Neil Partington, 'Beyond the 'Tomlinson Trap': Analysing the Effectiveness of Section 1 of the Compensation Act 2006' [2016] 37 Liverpool Law Review 33; Rachael Mulheron, 'Legislating Dangerously: Bad Samaritans, Good Society, and the Heroism Act 2015' (2017) 80 The Modern Law Review 88. See also The Scout Association v Barnes [2010] EWCA Civ 1476.

${ }^{6}$ For an example where rescuers aborted a rescue mission, see Julian Fulbrook, 'Rescuers and the Concept of a "Negligent Rescue"' (2013) Journal of Person Injury Law 81, 94.

${ }^{7}$ We do not look into the liability for intentional wrongdoing.

${ }^{8}$ The perception of liability is an empirical problem and we plan to conduct future research.

9 Gerwyn L H Griffiths, 'The Standard of Care Expected of a First-Aid Volunteer' (1990) 53 The Modern Law Review 255; Fulbrook (n 6).
} 
associated with altruistic behaviour. Here we investigate the concept of duty of care and the question of breach. Following our legal analysis, we progress to explore the behavioural aspects of law, examining some of the known biases that may contribute towards certain perceptions of the law and how it operates. We then provide an overview of some of the factors that may cause reluctance among certain members of society to provide help when it would easily be within their gift to do so. Section 5 concludes.

\section{Setting the Scene}

From the outset, it is prudent to define what we mean by altruistic acts and which activities we are going to exclude from our subsequent analysis. The National Survey of Volunteering and Charitable Giving defines volunteering as "[a]ny activity which involves spending time, unpaid, doing something which aims to benefit someone (individuals or groups) other than or in addition to close relatives, or to benefit the environment." ${ }^{10}$ Batson and Shaw suggest the following: "Altruism is a motivational state with the ultimate goal of increasing another's welfare." 11 Thus, giving unpaid time to do something that ultimately increases the welfare of others (or attempts to increase the welfare of others) is our working definition of altruism. When we use the term volunteer or rescuer in this article, we refer to a person acting altruistically as we have outlined in this section.

Most acts of altruism are simple and are undertaken in the course of everyday life. Acts performed by ordinary citizens such as helping a visually impaired person to cross a busy road, offering to assist an elderly person in unloading her shopping bags, or clearing snow from footpaths. It is important to remember that not every act of altruism need involve a rescue, nor will every act necessarily engage a professional person whose training and skills could be usefully deployed in an emergency situation. The vast majority of help is offered by individuals who have no particular skill or training. The focus of our investigation is on voluntary acts of assistance or help, in whatever form they may take, provided by non-professional members of the public. Thus, we would include within this definition situations in which a passer-by assists a fellow citizen in the form of helping him to move or transport an item of property. Moreover,

\footnotetext{
${ }^{10}$ Low and others (n 1) 10. See also Compact, 'Volunteering, Compact Code of Good Practice' (2005) www.compactvoice.org.uk/sites/default/files/volunteering.pdf 4.

${ }^{11}$ C. D Batson and Laura L Shaw, 'Evidence for Altruism: Toward a Pluralism of Prosocial Motives' (1991) 2 Psychological Inquiry 107, 108.
} 
within the ambit of our definition, we would also include more general voluntary acts aimed at benefiting not just one individual, but members of the public at large. One illustration could perhaps be clearing snow from the pavement or voluntarily spreading grit on the roads in icy conditions. The potentially far-reaching nature of these examples naturally indicates that our analysis is not limited solely to the rescue-type scenario, although, of course, this type of example could fall within the reach of our definition should it involve an ordinary citizen attempting to rescue another person who was in imminent danger. On this point, there is another side to consider, which focuses on the potential harm that a rescuer could suffer. In this situation, the legal debate centres on the extent to which the rescuer should be able to recover damages from a defendant who creates a dangerous situation. ${ }^{12}$ While we feel it is important to at least acknowledge this flip side of the coin, our analysis is only concerned with the potential liability of rescuers.

Falling outside the boundaries of our definition would be acts of assistance provided by professionals, such as those undertaken by the fire, ambulance, police and coastguard services. We also exclude from our analysis voluntary acts of altruism performed by off-duty doctors, and General Practitioners outside their patient catchment areas. ${ }^{13}$ Whilst we acknowledge that any assistance provided by doctors and General Practitioners acting outside the sphere of their direct professional obligations maybe viewed as voluntary and altruistic behaviour, we would argue that they have professional skills and competencies which place them in a different position to those who do not possess such attributes. There are a number of reasons for narrowing our research to non-professional actors. The broad principles of negligence apply to both amateurs and professionals. However, the legal difference lies in the standard of care that is expected should a professional choose to act. ${ }^{14}$ McNair J explained that "[t]he test [for professionals] is the standard of the ordinary skilled man exercising and professing to have that special skill" rather than the man on the Clapham Omnibus. ${ }^{15}$ In addition to the higher standard of care for professional rescuers, many professional rescuers act in the course of their employment. In Capital \& Counties plc v Hampshire County Council it was suggested that the rescuer who receives a salary or some kind of compensation for the services provided is not

\footnotetext{
${ }^{12}$ See Chadwick v British Railways Board [1967] 1 WLR 912; Baker v TE Hopkins \& Son Ltd [1959] 1 WLR 966.

${ }^{13}$ See Kevin Williams, 'Doctors as Good Samaritans, Some Empirical Evidence Concerning Emergency Medical Treatment in Britain’ (2003) 30 Journal of Law and Society 258.

${ }^{14}$ Bolam v Friern Management Hospital Committee [1957] 2 All ER.

15 ibid.
} 
normally regarded as a volunteer. ${ }^{16}$ Thus a person acting in such a capacity would not fall under our definition of an altruistic actor. As we have outlined above, altruistic acts are provided without payment or compensation. Another complication arises from the fact that the government frequently funds rescuers such as the emergency services or the police. Accordingly, it would be rather difficult to separate the issue of public authority liability from the problem of liability for altruistic misfeasance.

The separation between professionals and amateurs is relatively straightforward, yet there is a potential grey area surrounding volunteers who may have some training and qualifications, but who are not technically classed as professionals. Irrespective of any training and qualifications that an individual may have, judges in England tend to accept that volunteers are not judged according to a professional standard. ${ }^{17}$ Thus, our interest focuses on whether or not the apparent judicial sympathy towards volunteers is recognised in a way that could usefully encourage acts of altruism.

There is also a question about the effect that media reporting has on the mind-set of would-be helpers. As we will show below, news reports of accidents and potential liability in the context of volunteering may feed the perception that helping others may be costly. It may cause members of society to feel wary about performing certain helpful activities for fear of any legal consequences that may ensue should something untoward happen as a result of their efforts. Citizens' overestimation of the potential imposition of liability for altruistic acts could be contributing to a culture of passive inaction within society.

\section{Altruistic Behaviour: The Legal Position in England}

The examples we have outlined above offer different challenges for the tort of negligence. In some instances, the question is whether a duty of care exists. In most cases, however, commentators focus on the aspect of breach of duty and the potential deterrent effect of liability on socially desirable activity. In the first part of our analysis, we consider whether the helper owes a duty of care to an injured party. We will then review the breach of duty problems.

\footnotetext{
${ }^{16}$ Capital \& Counties Plc v Hampshire County Council [1997] EWCA Civ 3091; Kent v Griffiths [2000] EWCA Civ 3017 at [19].

${ }^{17}$ See Vowles $v$ Evans [2003] EWCA Civ 318.
} 


\subsection{Duty of care}

In the absence of exceptional circumstances, the law does not recognise a duty to act. Thus, a non-helper does not normally owe a duty of care in instances where he fails to intervene. This legal position is based largely on a range of policy considerations, illuminated neatly by Lord Hoffmann in Stovin $v$ Wise. ${ }^{18}$ He identified political, moral and economic arguments in support of the law's position. In political terms it is less of an invasion of an individual's freedom for the law to require him to consider the safety of others in his actions than to impose upon him a duty to rescue or protect. In a moral sense, it would be difficult to ascertain who, in fact, should be liable, for a duty to prevent harm to others or to render assistance to a person in danger may apply to a large and indeterminate class of people who happen to be able to do something. From an economic perspective, whereas having to pay compensation for loss caused by negligent conduct acts as a deterrent against increasing the cost of the activity to the community and reduces externalities, no similar justification exists for requiring a person who is not doing anything to spend money on behalf of someone else. ${ }^{19}$ Nevertheless, what if a person decides to come to the rescue of another without being obliged to do so or, more generally, voluntarily helps her neighbour? If that person voluntarily decides to act and causes harm to the claimant or the claimant's property, the question arises whether the defendant owes the claimant a duty of care.

The courts prefer to use existing categories to incrementally develop the duty of care and it is useful to consider the principles articulated in Caparo v Dickmann. The claimant must show that there was proximity between the claimant and the defendant; that damage to the claimant was foreseeable; and that it is fair, just and reasonable to impose a duty of care on the defendant. ${ }^{20}$ The foreseeability element is unlikely to be problematic; careless conduct, even with the best of intentions, creates a risk of harm. Provided it is reasonably foreseeable that some physical injury or damage to property could have occurred from the defendant's careless conduct, then the foreseeability element to the duty will be satisfied. Indeed, in Mitchell $v$ Glasgow CC it was stated that 'the concept of reasonable foreseeability embraced a wide range of degrees of possibility, from the highly probable to the possible but highly improbable,21,

\footnotetext{
${ }^{18}$ Stovin v Wise [1996] AC 923.

19 ibid at 943-944.

${ }^{20}$ Caparo v Dickmann [1990] 2 A.C.

${ }^{21}$ [2009] UKHL 11 at [18], per Lord Hope. See also Lord Nicholls in A-G (British Virgin Islands) v Hartwell [2004] UKPC 12.
} 
prompting Rachael Mulheron to conclude that 'this sets a very undemanding test'. ${ }^{22}$ Hence, foreseeability alone does not create a duty of care. ${ }^{23}$

With the above in mind, we now focus on the proximity between claimant and defendant and the categories of duty of care that have been created for Good Samaritans and volunteers. Since no duty of care is owed to the public at large, the element of proximity identifies the individual "[...] who is so closely and directly affected by your act that you ought reasonably to have him in contemplation as being so affected when you are directing your mind to the acts or omissions which are called in question." 24

In Capital \& Counties the Court of Appeal discussed two possible approaches to deal with proximity in rescue scenarios. ${ }^{25}$ Proximity can be established where the defendant had control over the danger or created the risk that ultimately materialised. Alternatively, “[...] proximity will arise [...] where someone possessed of a special skill undertakes, quite irrespective of contract, to apply that skill for the assistance of another person who relies upon such skill, and there is direct and substantial reliance by the plaintiffs on the defendant's skill.",26 In Capital \& Counties the Court of Appeal recognised that rescuers normally become active when there is already a danger or risk that was created by the claimant, third parties or act of God. As long as the existing risk materialises no duty of care is owed. As for a new risk created by the rescuer himself, the courts have held that the defendant may owe a duty of care to the claimant: “....where the rescue/protective service itself by negligence creates the danger which caused the plaintiff's injury there is no doubt in our judgment the plaintiff can recover." ${ }^{27}$ It is crucial therefore to distinguish between the failure to provide an adequate service - for which a duty of care may not be owed ${ }^{28}$ - and the creation of a new risk or source of harm through unskilful intervention - which can create liability. In Kent v Griffiths Lord Woolf MR identified two potential types of case in which a volunteer may owe a duty of care: ${ }^{29}$ the 'adding damage scenario', relying on East Suffolk Rivers Catchment Board v Kent, ${ }^{30}$ and a scenario in which the helper causes damage beyond that harm the claimant would have suffered anyway,

\footnotetext{
22 Rachael Mulheron, Principles of Tort Law (CUP 2016) 53.

${ }^{23}$ McLoughlin v O'Brian [1983] 1 AC 410, 420, per Lord Wilberforce.

${ }^{24}$ Donoghue v Stevenson [1932] AC 562, 580 per Lord Atkin.

${ }^{25}$ Capital \& Counties Plc v Hampshire County Council (n 16).

${ }^{26}$ ibid.

27 ibid.

${ }^{28}$ Ambulance services may owe a duty of care for failure to provide an adequate service, see Kent $v$ Griffiths (n 16).

${ }^{29}$ Kent v Griffiths (n 16) at [15].

${ }^{30}$ East Suffolk Rivers Catchment Board v Kent [1940] A.C. 74, 102.
} 
supported by the ruling in Horsley v MacLaren (The Ogopogo). ${ }^{31}$ Thus, if a rescuer attempts to help a victim, he owes a duty not to create an additional risk or harm greater than the victim would have suffered anyway. ${ }^{32}$

Alternatively, the claimant may assert that she relied on the defendant's skill in performing the rescue. ${ }^{33}$ In Capital \& Counties it was argued that the rescuer assumes a duty to be careful when attempting the rescue, based on the assumption of responsibility principle developed in Hedley Byrne \& Co. v Heller \& Partners. ${ }^{34}$ The relationship can be based on an undertaking and the victim's reliance on it, or the rescuer's assumed control of the danger. ${ }^{35}$ The Court of Appeal rejected this approach with regard to fire services, arguing that, even in a failed rescue attempt, the victim would not have been in a worse situation: "It is not clear why a rescuer who is not under an obligation to attempt a rescue should assume a duty to be careful in effecting the rescue merely by undertaking the attempt." ${ }^{, 36}$

So far, we have discussed the legal framework that specifically applies to rescuers but, as we have pointed out above, this article principally seeks to assess the liability of nonprofessional volunteers, whose actions may not fit within a 'rescue' type scenario. What is the situation then in regard to more routine acts of altruism, such as, say, clearing snow? Applied to acts of altruism, the 'creating a new or additional harm' and 'assumption of responsibility' tests are rather broad and could include most if not all types of volunteering and helping. The 'creating a new or additional harm' test would especially apply to many instances in which the volunteer's activity has increased the risk of injury. There are a range of different examples of altruistic activities that could be used to illustrate some of the conceptual difficulties in the application of the law in general, and in particular the conceptual difficulties surrounding the 'new risk test'. These could include, amongst others, cleaning leaves from footpaths in the autumn, cutting overgrown hedges that have infringed on public footpaths, cleaning a local

\footnotetext{
${ }^{31}$ Horsley v MacLaren (The Ogopogo) [1971] R.C.S. 441.

${ }^{32}$ East Suffolk Rivers Catchment Board v Kent (n 30) 102.

${ }^{33}$ The assumption of responsibility test was successfully applied in Watson v British Boxing Board of Control Ltd [2000] EWCA Civ 2116. The Court of Appeal held that a boxing association assumes responsibility for the well-being of a boxer. Rescuers who worsen the situation of the victims have also been discussed with regard to the concept of detrimental reliance - circumstances in which the claimant changes his behaviour for the worse, trusting the rescuer's intervention, Jeroen Kortmann, Altruism in Private Law - Liability for Nonfeasance and Negotiorum Gestio (OUP 2005) 62.

${ }^{34}$ Hedley Byrne \& Co. v Heller \& Partners [1964] AC 465; see also Henderson v Merrett Syndicates Ltd [1994] UKHL 5. With criticism: Kit Barker, 'Unreliable Assumptions in the Modern Law of Negligence' (1993) 109 Law Quarterly Review 461. The courts apply Hedley Byrne to a wider range of scenarios than just negligent misstatements as in the original case. The Supreme Court reiterated the wider application in Michael $v$ Chief Constable of South Wales Police [2015] UKSC 2 para 67.

${ }^{35}$ Kortmann (n 3339) 44ff.

${ }^{36}$ Capital \& Counties Plc v Hampshire County Council (n 16) at [58].
} 
park or maintaining community green spaces. For the purposes of consistency, our analysis focuses on the key example of snow clearing, although the legal and interpretational problems we expose throughout could equally apply to any of the above examples, and indeed more.

In the snow clearing scenario, then, we first need to distinguish between scenarios where a volunteer has actually made the situation worse by, for example, adopting a careless technique to remove snow, and those instances where the snow was cleared in accordance with government guidelines and the exercise of reasonable care. ${ }^{37}$ In the former case, we will experience few problems establishing proximity and, thus, a duty of care applying Capital \& Counties as the volunteer has created a new sources of harm. The latter case is more difficult to assess. The individual who clears the pavement from snow actually reduces the risk of injury because it is safer to walk on a cleared footpath rather than on ice and snow. If we applied the test outlined in Capital \& Counties, the helper does not owe a duty of care to the unlucky victim who injures himself slipping on the cleared path unless the risk of slipping after clearing the path is defined as a new risk, compared to the original risk of merely slipping on undisturbed snow. ${ }^{38}$ This interpretation of the 'new risk' test ignores the fact that any snow-clearing actually reduced the overall risk of injury, and instead focuses on the new risk of harm created by the intervention. This seems to disadvantage non-professional, non-rescuer volunteers in the context of duty of care. Unlike professional or trained rescuers, volunteers are more likely to create or contribute to the risk that crystallises because trained rescuers normally "[...] act in the context of a danger already created and damage already caused [... ${ }^{\prime 39}$. Thus, if the risk criterion is used to establish proximity, there is a strong case for imposing a duty of care on the volunteer or helper when she causes injury, for it is normally her who is actually responsible for creating that new or additional risk of harm. ${ }^{40}$

The 'assumption of responsibility' approach is equally likely to lead to an arbitrary distinction between situations in which a duty of care is owed and where one is not. By way of illustration, it is doubtful that the volunteer clearing snow purports to have a special skill on

\footnotetext{
${ }^{37}$ See, for example, the guidance available at https://www.gov.uk/clear-snow-road-path-cycleway.

${ }^{38}$ One could argue that the hapless helper created a new risk by clearing the path that is different from the slipping risk on snow.

${ }^{39}$ Capital \& Counties Plc v Hampshire County Council (n 16) at [33]. The quote continues: "[...] whether by the forces of nature, or the acts of some third party or even of the plaintiff himself, and whether those acts are criminal, negligent or non-culpable."

${ }^{40}$ The Law Reform Commission, Consultation Paper: Civil Liability of Good Samaritans and Volunteers (Dublin 2007) 89.
} 
which the claimant can reasonably rely. Even in circumstances where one could think of special skills, it is doubtful that the victim reasonably relied on that expertise. ${ }^{41}$

It is unrealistic to expect that the law will respond with a single legal test to the multitude of situations in which an altruistic act may go wrong. Despite the more theoretical than real risk of liability, from a policy point of view it would be desirable if the law could send a strong signal to volunteers that there is little to fear from mishaps that occur in the course of volunteering, but neither the 'new risk' test nor the 'assumption of responsibility' test provide that certainty. As relationships can differ from scenario to scenario, the proximity criterion fails to provide a conclusive answer as to the duty owed by volunteers to third parties.

The case law on rescue scenarios favours the risk of injury as an element to establish proximity and, thus, a duty of care. By analogy, we argue that the risk of injury test can also be utilised for imposing a duty of care in non-rescue, altruistic actions that have led to injury. The other question to consider at this point is whether the imposition of a duty should be precluded on the grounds of it not being fair, just and reasonable. Public policy considerations limit liability in certain areas, such as actions of public authorities, ${ }^{42}$ pure psychiatric injury ${ }^{43}$ and pure economic loss. ${ }^{44}$ These types of public policy concerns are arguably less relevant in the context of liability for altruistic acts, for imposing a duty on a volunteer is unlikely to be inconsistent with any wider objective of the law, nor would it unreasonably impinge upon the interests of any one party. However, in Capital \& Counties Stuart-Smith LJ suggested that “...if [...] investigation of the allegedly negligent conduct would itself be undesirable and open to abuse by those bearing grudges, the law will not impose a duty." 45 Thus, one element to consider in the realms of policy, is the desirability of altruistic activity. A closer look at this policy consideration though reveals that it is usually dealt with when assessing the standard of care, and so we will discuss the 'public interest in volunteering' in that context. At present, we would argue that there are no convincing policy reasons to exclude a duty being imposed on volunteers in principle and would thus conclude that those who act altruistically but cause harm in the process would owe a duty of care to the victim.

\footnotetext{
${ }^{41}$ But see Chaudhry v Prabhakar [1989] 1 WLR 29 where the court dealt with an unpaid adviser as gratuitous agent as well as negligent misrepresentation according to Hedley Byrne v Heller (n 34).

${ }^{42}$ Hill $v$ Chief Constable of West Yorkshire [1987] UKHL 12.

${ }^{43}$ Alcock $v$ Chief Constable of South Yorkshire [1991] UKHL 5.

${ }^{44}$ Spartan Steel and Alloys Ltd. v Martin \& Co Ltd. [1972] EWCA Civ 3.

${ }^{45}$ Capital \& Counties Plc v Hampshire County Council (n 16) at [74].
} 


\subsection{Standard of care}

We have identified that the imposition of a legal duty may be largely unproblematic where a person undertakes to perform a task of his or her own volition, so we now turn our attention to the question of breach of duty. Alderson B described negligence as 'the omission to do something which a reasonable man, guided upon those considerations which ordinarily regulate the conduct of human affairs, would do, or doing something which a prudent and reasonable man would not do. ${ }^{46}$ With this in mind, two questions are pertinent: what standard of care does the law require from a volunteer when he performs an altruistic act? How should the law account for the utility of the volunteer's action?

In most situations, volunteers will lack the special skills required to help but, at the same time, many of these activities can also be provided by professionals. For example, a rescuer may have no first-aid experience, or be a retired physician who actually knows how to provide medical assistance. Which standard will apply to them: that of an untrained amateur, that of a trained first-aider or that of a trained doctor? In Cattley v St John's Ambulance Brigade Prosser QC suggested to apply the standard of a first-aider to a trained rescuer: "[...] the true test for establishing negligence in a first-aider is whether he has been proved to be guilty of such failure as no first-aider of ordinary skill would be guilty of, if acting with ordinary care." ${ }^{, 47}$ In Prosser's view the correct standard of care is that of an ordinary person professing to have a special skill as per Bolam v Friern Management Hospital. ${ }^{48}$ In Vowles v Evans Lord Phillips referred obiter to the skill level expected from a volunteer, stating that "[...] sometimes in the case of amateur sport, the referee fails to turn up, or is injured in the course of the game, and a volunteer referee is called for from the spectators. In such circumstances the volunteer cannot reasonably be expected to show the skill of one who holds himself out as referee, or perhaps even to be fully conversant with the Laws of the Game." 49 Lord Phillips made clear that the volunteer's action should be judged according to a more forgiving standard.

A similar line of argument was applied to other rescuers who were not expected to reach a professional skill level. In Horsley v MacLaren (The Ogopogo), the Canadian Supreme Court was sympathetic to a defendant who attempted to rescue a passenger when the latter fell

\footnotetext{
${ }^{46}$ Blyth v Birmingham Waterworks [1856] 156 ER 1047 at 1049.

${ }^{47}$ Cattley v St John's Ambulance Brigade [1988] Lexis Citation 1703, 6-7.

${ }^{48}$ Bolam v Friern Management Hospital Committee (n 14). See also the Bolitho qualification of the Bolam test. Bolitho $v$ City and Hackney Health Authority [1997] UKHL 46.

${ }^{49}$ Vowles v Evans [2003] (n 17) 328. The law of negligence does not usually take account of the inexperienced actor, Nettleship v Weston [1971] 2 QB 691 (CA); Wilsher v Essex AHA [1987] EB 730 (CA) but does adjust the standard of care in accordance with the specialism and skill level of the defendant, Bolam (n 14).
} 
overboard from the defendant's cruiser. A question arose as to whether a textbook procedure would have saved the claimant, yet, as it could not be said that the botched rescue attempt had demonstrably worsened the claimant's position, no liability was imposed. If, however, it could be established that a rescue attempt worsened the situation for the rescued, it was suggested that this could lead to negligence liability. It was equally stressed that all circumstances must be taken into account and "existing circumstances of emergency" may help to excuse mistakes or procedures that were carried in a non-standard manner. ${ }^{50}$

The courts have consistently stressed that the individual circumstances must be taken into account when determining whether the defendant took reasonable care. ${ }^{51}$ In Day v High Performance Sports Ltd Hunt J held that the circumstances of the rescue must be taken into account and a hindsight bias should be avoided. ${ }^{52}$ He refused to impose liability on a climbing centre in which the claimant was injured, arguing that it did not breach its duty towards the claimant by attempting an unsuitable rescue procedure. The court's decision was influenced by the fact that the claimant's injury would have occurred in any case and a suitable rescue attempt would have been too late.

In Smoldon v Whitworth it was held that in order to assess the standard of care exercised by a rugby referee "[ $t]$ he level of care required is that which is appropriate in all the circumstances, and the circumstances are of crucial importance. ${ }^{, 53}$ It is particularly interesting to note that "[f]ull account must be taken of the factual context in which a referee exercises his functions, and he could not be properly held liable for errors of judgment, oversights or lapses of which any referee might be guilty in the context of a fast-moving and vigorous contest. The threshold of liability is a high one." ${ }^{, 54}$ Lord Phillips MR shared Lord Bingham's assessment in another rugby case where the game ended with tragic injury. ${ }^{55}$ In Vowles $v$ Evans, he held that an amateur rugby referee owed a duty of care to the players under his charge and breached that duty by failing to implement the rules that were supposed to protect the players from injury. The decisions have been criticised as potentially deterring amateurs from taking the whistle

\footnotetext{
${ }^{50}$ Horsley v MacLaren (The Ogopogo) (n 31) 452.

${ }^{51}$ Watt v Hertfordshire County Council [1954] 1 W.L.R. 835.

${ }_{52}$ Day v High Performance Sports Ltd [2003] EWHC 197 (QB). See also Eckersley and others $v$ Binnie and others [1988] 18 ConLR 1. The threshold for establishing a breach has been set at a high level between spectators and participants in sport events, Wooldridge v Sumner [1963] 2 QB 43, Caldwell v Maguire [2001] EWCA Civ 1054.

${ }_{53}$ Smoldon v Whitworth [1996] ELR 249256.

54 ibid. See also Caldwell v Maguire Fitzgerald (n 52).

55 Vowles v Evans (n 17) 326.
} 
and refereeing a game for fear of liability. ${ }^{56}$ Lord Phillips asserted in Vowles $v$ Evans that the liability threshold for amateurs stepping in is a high one. ${ }^{57} \mathrm{He}$ addressed the potential deterrent effect of the court's decision on volunteers by stressing, obiter, the low probability of severe injury and, consequently, the low probability that someone is held liable. Liability in Vowles $v$ Evans was established based on the particular facts, i.e. the failure to implement the rules of the game. We agree that the injuries in both Smoldon $v$ Whitworth and Vowles v Evans were extreme. However, the failure to implement the rules of the games may not be as uncommon as their Lordships claim. Overall, the legal nuances of the decisions may be lost on the amateur and the message received from those decisions may suggest a propensity for liability. ${ }^{58}$ Smoldon $v$ Withworth and Vowles $v$ Evans can be treated as exceptions to the general rule; arguably they do not change the overall picture of lenient legal treatment of volunteers and helpers. Nonetheless, whether this message has been accurately conveyed to the public is rather doubtful. ${ }^{59}$

How can we apply the lessons from rescue situations and amateur sports to volunteers and helpers in other areas? It is clear that the individual circumstances determine whether there is a breach of duty. Clearing snow from a pavement, for example, may not completely remove the risk of slipping, but it does actually make walking safer. Thus, any error on the part of a defendant would need to be severe for liability to be imposed. The courts are also obliged to take into account the surrounding circumstances, such as the priority that a Council would attach to clearing a particular road and any delay that may have occurred. Given the costs incurred, some Councils may demonstrate apathy towards dealing with snow and so in many cases it may not have been cleared had it not been for the intervention of a defendant. These are all considerations which could, potentially, operate in a defendant's favour. ${ }^{60}$

Another aspect of volunteering is the fact that altruistic acts provide benefits for society. The question is whether and how these benefits are taken into account when assessing the four factors that govern the breach of duty. ${ }^{61}$ That the value of a particular activity should be part

56 http://www.independent.co.uk/news/rugby-case-changes-rules-of-game-1305736.html (accessed 09 September 2016). See also David McArdle, "The Enduring Legacy of "Reckless Disregard"' (2005) 34 Common Law World Review 316.

${ }^{57}$ See Vowles $v$ Evans (n 17).

${ }^{58}$ Lord Phillips seems to assume that the Court's decision will have no deterrence effect.

59 This point was made earlier by Rob Heywood and Peter Charlish, 'Schoolmaster Tackled Hard Over Rugby Incident' (2007) 15 Tort Law Review 162.

${ }^{60}$ David Quarmby, 'The Resilience of England's Transport Systems in December 2010, an Independent Audit by David Quarmby CBE' (2010) para 3.37.

${ }^{61}$ The courts consider four factors when assessing a breach of duty: the probability of injury, the severity of the potential injury, the cost of preventing that injury and the social utility of the activity in question, Bolton $v$ Stone 
of the breach of duty analysis is not in doubt, ${ }^{62}$ but how much weight should be given to the benefit of an activity is where the contention lies. In Watt v Hertfordshire County Council, while on a journey to attend an emergency, a fireman was injured by a heavy jack which had been inappropriately secured in the back of a lorry. It was held that the fire authorities were not negligent in requiring firemen to take abnormal risks, which they were prepared to take in order to save life and limb. Lord Denning reasoned that the existence of an emergency, coupled with the need to act urgently in order to save life, justified the risk of transporting the jack in the manner that it was in the case. ${ }^{63}$ Thus, the public utility of the fire service was key factor in determining the question of breach. An unavoidable consequence of a fireman's job is that sometimes additional risks will need to be taken in order to save lives and safeguard the public. As firemen should expect this, it followed that a degree of leniency should be shown to the fire authorities. We might also argue that the same degree of latitude should equally apply to altruistic volunteers, because they often act out of a feeling of social responsibility, providing a useful service to society, which should accordingly be considered in the assessment of breach. From a different perspective, Lord Denning also gave an example of when, after undertaking a cost-benefit analysis, the decision in Watt may have gone the other way. He stated: "One must balance the risk against the end to be achieved. If this accident had occurred in a commercial enterprise without any emergency there could be no doubt that the servant would succeed." 64 On the commercial point, we have already noted that volunteers' actions are characterised by giving without being paid or receiving consideration. ${ }^{65}$ Thus, the noncommercial nature of the activity, or, to be more precise, the fact that volunteers give without receiving payment in return, ${ }^{66}$ is a criterion that also ought to weigh heavily in favour of the defendant when assessing a breach of duty.

The importance of weighing the benefits of a particular activity for society was stressed by the House of Lords in Tomlinson v Congleton Borough Council. ${ }^{67}$. Tomlinson was not a rescuer case but it is an important decision as the House of Lords stressed the importance of taking into account the social value of an activity when considering a breach of duty, individual

[1951] A.C. 850 and Tomlinson v Congleton Borough Council [2003] UKHL 47. For an in-depth analysis see, for example, Mulheron (n 22) $353 \mathrm{ff}$.

${ }^{62}$ Daborn v Bath Tramways Motor Co Ltd [1946] 2 All ER.

${ }^{63}$ Watt v Hertfordshire County Council (n 51).

${ }^{64}$ Watt v Hertfordshire County Council (n 51) 838.

${ }^{65}$ See section 2.

${ }^{66}$ See our working definition of altruistic actions in section 2.

${ }^{67}$ Tomlinson v Congleton Borough Council (n 61). 
responsibility. Their Lordships also expressed a distaste for defensive measures implemented to prevent perceived liability that would deprive society of beneficial activities. ${ }^{68}$ Although Lord Hoffmann held that the defendant owed no duty of care under the Occupiers' Liability Acts 1957 and 1984, he continued his analysis of breach, assuming that such duty existed: ${ }^{69}$ "[...] the question of what amounts to "such care as in all the circumstances of the case is reasonable" depends upon [...] the social value of the activity which gives rise to the risk and the cost of preventative measures." ${ }^{70} \mathrm{He}$ sought to encourage lawful and socially useful activities that could create cost savings. ${ }^{71}$ There is no doubt that the benefits of such activities must be weighed against the risks created and that this is a question of degree and facts. ${ }^{72}$ The social value of an activity will not always trump other factors such as probability of risk and severity of harm, but it appears that only instances that resemble gross negligence override the social benefits. ${ }^{73}$

The House of Lord's attempt in Tomlinson to reassure volunteers and reduce the propensity to engage in defensive practices triggered a debate that ultimately led to the enactment of section 1 of the Compensation Act 2006, and the Social Action, Responsibility and Heroism Act 2015. Section 1 of the Compensation Act 2006 reminds a court that setting the standard of care that a reasonable person ought to meet has a knock-on effect on the incentives of individuals to undertake 'desirable activities', but it also sought to address a "[...] common misperception [of liability] that can lead to a disproportionate fear of litigation and consequent risk-averse behaviour". ${ }^{74}$ Considering the standard of care in negligence or breach of statutory duty, the court may have regard to the potential deterrence effect of finding liability. According to Section 1, the court should, when "determining whether the defendant should have taken particular steps to meet a standard of care [...], have regard to whether a requirement to take those steps might

(a) prevent a desirable activity from being undertaken at all [...], or

(b) discourage persons from undertaking functions in connection with a desirable activity."

\footnotetext{
${ }^{68}$ Tomlinson v Congleton Borough Council (n 61) at [44].

${ }^{69}$ ibid at [29].

${ }^{70}$ ibid at [34].

71 ibid at [36].

72 The Scout Association v Barnes (n 5) 49.

${ }^{73} \mathrm{ibid}$. For other factors see, for example, Bolton $v$ Stone (n 61). Wooldridge v Sumner (n 52) has sometimes been interpreted as advocating a 'reckless disregard' standard.

${ }^{74}$ Compensation Act 2006 - Explanatory Notes at [7], see also Better Regulation Task Force, 'Better Routes to Redress' (2004).
} 
This can apply to both voluntary actions and altruistic acts, thereby acknowledging that these activities are desirable and that volunteers could be deterred if the courts were too quick to impose liability. In a number of cases the courts have taken Tomlinson and section 1 into account, often observing that section 1 adds nothing to the common law. ${ }^{75}$ Since the law does not suggest immunity for injury caused by a negligent volunteer, the existing weighing test continues to determine whether a helper breached a duty of care. ${ }^{76}$ Commentators have criticised this approach for eroding the reasonable person standard, effectively creating a more variable standard. ${ }^{77}$

If there was doubt as to the factors that should be taken into account when determining the liability of a volunteer, the Social Action, Responsibility and Heroism Act 2015 (SARAH) clarifies that social benefits have to be considered. ${ }^{78}$ According to section 2 , the court must scrutinise whether "[...] whether the alleged negligence or breach of statutory duty occurred when the person was acting for the benefit of society or any of its members." Thus, just like the Compensation Act 2006, SARAH did not amend the law but rather restated it. ${ }^{79}$ On the face of it, SARAH appears to support our argument that even if a duty of care is owed, the courts should not be too quick to hold that there has been a breach of that duty because of the benefits that are created by volunteers and good neighbours. However, section 3 requires the defendant to " [...] demonstrate [...] a predominantly responsible approach towards protecting the safety or other interests of others." This shifts the balance away from the benefits of the action and focuses more on the (avoidable) risks, a problem neatly captured in Scout Association $v$ Barnes. ${ }^{80}$ Here the claimant was injured while playing a game in the dark at a scout meeting. It was argued on appeal that the trial judge had given insufficient weight to the social value of the activity. The Court of Appeal accepted that scouting activities were valuable to society and often contained elements of risk. However, it confirmed the trial judge's decision that playing in the dark significantly increased the risk of injury and that the only justification was the

\footnotetext{
${ }^{75}$ Uren v Corporate Leisure (UK) Ltd [2010] EWHC 46 (QB) at [19] and [2011] EWCA Civ 66; The Scout Association v Barnes (n 5) at [49]; Wilkin-Shaw v Fuller [2012] EWHC 1777 (QB) at [46]; Cornish Glennroy Blair-Ford v CRS Adventures Limited [2012] EWHC 2360 QB at [45], [52] and [56]; Humphrey v Aegis Defence Services Ltd [2016] EWCA Civ 11 at [14]. See also Partington (n 5); Mulheron (n 5).

76 The Scout Association v Barnes (n 5).

77 Partington (n 5) 42.

${ }^{78}$ For an insightful commentary, see James Goudkamp, 'Restating the Common Law? The Social Action, Responsibility and Heroism Act 2015' (2017) Legal Studies (early view).

${ }^{79}$ For marked criticism, see (Lord Pannick) HL Deb 06 January 2015, vol 758, col 262; Jon Robins, 'A Policy Turkey' (2014) 164 New Law Journal 8; Howard Fidderman, 'When Will this Madness End' (2014) Health and Safety Bulletin 1; Mulheron (n 5).

${ }^{80}$ The Scout Association v Barnes (n 5).
} 
additional excitement. A similar version of the game could have been easily played in the light without reducing the educative value. ${ }^{81}$ One potential problem therefore is that section 3 could very well undermine the useful intentions underpinning section 2 because individuals do not know ex ante what constitutes a responsible approach.

SARAH, and to a lesser extent section 1 Compensation Act 2006, have been criticised for not changing the law, but for merely aiming to change the perception of liability risks. ${ }^{82}$ Even the drafters of the Explanatory Memorandum of the Compensation Act thought that the purpose of section 1 Compensation Act 2006 rests primarily in reassuring volunteers and improving awareness of this aspect of the law. ${ }^{83}$ As for the substantive assessment of breach of duty, the more recent case law does not show a material impact of section 1 on the assessment of breach of duty. ${ }^{84}$ Judges frequently state that section 1 restates the common law and usually mention it in passing. ${ }^{85}$

In sum, whilst it is clear that the imposition of a duty would be relatively straightforward in respect of one who voluntarily undertakes to assist another, in terms of the actual assessment of breach, we contend that the courts would be sympathetic to the rescuer. Judges have to weigh the various factors that determine a breach of duty, but they also need to take into account the potential deterrent effect on desirable activities. ${ }^{86}$ Thus, we would expect a lenient legal treatment of mishaps that occurred in the course of altruistic activities.

\section{Perception of liability}

So far we have analysed the legal framework that governs liability for altruistic acts. We have shown that the threshold for the imposition of liability is high. ${ }^{87}$ The question is whether this message is more widely communicated, and understood, beyond mere legal circles. It is said

\footnotetext{
${ }^{81}$ The Scout Association v Barnes (n 5).

${ }^{82}$ Mark Lunney, Donal Nolan, Ken Oliphant, Tort Law (6 $6^{\text {th }}$ edn, OUP 2017) 178; see also (n 79).

${ }^{83}$ Compensation Act, Explanatory Note Bill 155- EN, See also Ministry of Justice, 'Memorandum to the Justice Select Committee, Post-Legislative Assessment of the Compensation Act 2006' (2012).

${ }^{84}$ See case law in footnotes 75 and 85.

${ }^{85}$ See, for example, Hopps v Mott Macdonald Ltd \& Anor [2009] EWHC 1881 (QB); Uren v Corporate Leisure (n 75); Reynolds v Strutt \& Parker LLP [2011] EWHC 2263 (Ch); Sutton v Syston Rugby Football Club Ltd [2011] EWCA Civ 1182; Wilkin-Shaw v Fuller (n 75); Cornish Glennroy Blair-Ford v CRS Adventures Ltd (n 75); McErlean v St Bride's Primary School [2014] NIQB 1.

${ }^{86}$ The Scout Association v Barnes (n 5) at [49]. See also Horsley v MacLaren (the Ogopogo) (n 31).

${ }^{87}$ Hodgson of Astley Abbotts (n 3) 10: "Lawyers with whom we have discussed this have focused very much on this point of myth rather than reality."
} 
that the actions of many are misguided by the fear of liability - one of the elements of the ambiguous catchphrase 'compensation culture'. ${ }^{88}$ In this section, we will argue that due to certain biases, citizens tend to focus on reported cases of liability or incidences of outrageous claims (independent of their success) and that these cases have shaped the public perception of helpers' liability. We suggest that an overestimation of the potential to face liability is one possible deterrent to voluntary action (there are others such as time constraints). We will first explain some of those biases and then provide some evidence in relation to misperception of legal rules. In the final section, we argue that the principles articulated in section 1 of the Compensation Act 2006, and SARAH, should be communicated more effectively to correct any public misconceptions about the risk of incurring civil liability. ${ }^{89}$

\subsection{Insights from the UK}

Empirical evidence relating to liability for altruistic acts or the perception thereof is scarce. ${ }^{90}$ In the only English study of its kind, physicians in the Sheffield area were surveyed about their attitude and experience in regard to Good Samaritan situations. When asked to provide reasons for not assisting in a first-aid situation, 44 per cent out of 50 respondents cited the fear of being sued as one of the reasons for not assisting. ${ }^{91}$ While this was not the most important reason for doctors not assisting in first-aid situations, ${ }^{92}$ it shows that a considerable number of individuals have considered the liability issue. We have already acknowledged that a low risk of liability exists for helpers in general but the liability risk may be higher for professionals such as medics in Good Samaritan situations. ${ }^{93}$ To this end, the doctors in the Sheffield study were perhaps justified in feeling reluctant to provide help because they lacked the necessary skills and expertise to deal with emergencies; any doctor who does decide to stop and help but who fails to display appropriate medical skills when doing so is indeed at risk of being liable. ${ }^{94}$ However,

\footnotetext{
${ }^{88}$ Goudkamp (n 78) 5. Motivated reasoning may also partially explain the resistance to assist others. The unwillingness to help will post hoc be justified by reference to issues such as legal liability, hassle etc., see Ziva Kunda, 'The Case for Motivated Reasoning' (1990) 108 (3) Psychological Bulletin 480.

${ }^{89}$ More generally, a way of addressing the perception problem is to improve the way in which legal rules are communicated. Arguing along similar lines, see Hodgson of Astley Abbotts (n 3) 10.

${ }^{90}$ Luke Bennett and Carolyn Gibbeson, 'Perceptions of Occupiers' Liability Risk by Estate Managers' (2010) 2 International Journal of Law in the Built Environment 76, 77.

${ }^{91}$ Williams (n 13) 268.

92 The fear of being sued was ranked the $4^{\text {th }}$ most prevalent reason not to act out of eight (including 'others').

93 See section 2.

${ }^{94}$ A common reason identified for not offering assistance was that the participants did not feel they had the necessary skills to deal with emergency situations. Williams (n 13) 267.
} 
Williams also identified that the participants overestimated their potential exposure to legal action. ${ }^{95}$ Thus, while the risk may be 'real' in that there is a certain probability that a volunteer may be held liable, the limited evidence available indicates that few rescue/volunteer cases make it as far as court and, in those that do, we have seen that judges will adopt a lenient approach when it comes to determining the question of breach..$^{96}$ Thus, the probability of being sued may therefore be exaggerated.

Studies such as Williams' have a number of limitations and he acknowledged that it was beyond the scope of his survey to provide a full picture of participants' motivation to act as Good Samaritans. ${ }^{97}$ Nonetheless, it seems that the perception of liability is one of the factors that is relevant for those who provide aid and it is also a factor that is likely to be given the wrong weight due to erroneously estimated probabilities. Williams suggests that the understanding of legal rules is random. ${ }^{98}$ On the basis of William's study, we would argue that this is not just a random guess but a systematic misperception of negligence liability. ${ }^{99}$ If doctors were guessing legal rules randomly, they should have answered correctly in 50 per cent of the cases. ${ }^{100}$ Since the results from the survey were worse, one could suspect that professionals do not only lack knowledge of the negligence rules but may also systematically misinterpret the law and, thus, misconceive the risk of negligence liability.

We were not able to find a study that systematically explores volunteers' and helpers' perception of liability. ${ }^{101}$ One of the tentative hypotheses we extract from the Williams' work is that if a systematic misunderstanding of negligence liability for altruistic acts exists among medical professionals, it is probably even more widespread among the general public. Medical professionals normally receive some basic legal training as part of their schooling, whereas the general public do not. ${ }^{102}$ Thus, it seems more probable that the average individual with less knowledge of liability rules will be more likely to over- or underestimate the risk of being liable when helping others. This hypothesis needs to be tested, of course, but it receives some support

\footnotetext{
95 Ibid at 279.

${ }^{96}$ Indeed, Williams himself identifies that the evidence suggests that 'few (if any) claims are likely to be brought'. Ibid at 273.

97 ibid 265.

98 ibid 268.

${ }^{99}$ Assuming a sufficiently large sample and that the reported data are reliable.

100 This is akin to throwing a coin. One may observe a few heads or tails in a row but after a sufficiently large number of coin tosses, we should have roughly the same number of tosses that showed either heads or tails. If doctors have no knowledge about legal rules and randomly guessed the correct answer to the questions, 50 per cent of the answers in the sample should have been correct.

${ }^{101}$ The 'Helping Out' survey did not look at this in detail, Low and others (n 1).

102 Michael Preston-Shoot and Judy McKimm, 'Prepare for Practice? Law Teaching and Assessment in UK Medical Schools' (2010) 36 Journal of Medical Ethics 694-699.
} 
from Lord Hodgson, who was asked to investigate what stops people from giving time to charity. Analysing submissions from over 600 individuals and organisations, ${ }^{103}$ he identified a negative mind-set as one of the reasons that lowers the incentives to help. In his view, this negative mind-set manifests itself in an overly cautious attitude towards risk and the perception that "a lawyer, with a writ at the ready, waits around every corner." ${ }^{104}$ He states that "[r]ightly or wrongly the fear of becoming involved in litigation is a major preoccupation." 105 We prefer the expression of perception of liability to describe situations in which the erroneous fear of legal rules impedes acts that would be beneficial to society.

\subsection{Insights from behavioural sciences}

As we have argued earlier, volunteers perhaps harbour misconceptions about the actual extent of their legal exposure. In this section, we further substantiate our hypothesis by looking into human biases that shape the perception of risks. While the risk of liability is not quite the same as, for example, the risk of becoming the victim of a crime, behavioural sciences offer very useful observations with regard to human behaviour that could assist our argument. ${ }^{106} \mathrm{We}$ assert that the perception issue can, to a certain extent, be addressed by signalling, taking into account those human weaknesses. ${ }^{107}$ Consequently, legislative interventions, such as section 1 of the Compensation Act 2006 and SARAH 2015, could help to reassure lay people, but only if their guiding principles are effectively communicated to the public.

There is a general agreement that humans are not very good at judging risks and, consequently, it would seem at assessing the risk of liability. ${ }^{108}$ Humans generally tend to make predictable errors when assessing the probability of accidents or injury. ${ }^{109}$ The reason is that heuristics, the technical term for mental shortcuts or rules of thumb, help most of the decision-

\footnotetext{
${ }^{103}$ Lord Hodgson analysis is based on submissions of interested parties but, as far as we can tell, the report did not rely on a standard survey or random samples.

${ }^{104}$ Hodgson of Astley Abbotts (n 3) 4.

105 ibid 10.

${ }^{106}$ For an overview see Vivianne H M Visschers and Ree M Meertens, 'Associative and Cognitive Processes in Risk Perception and Communication' in Joana G Lavino and Rasmus B Neumann (eds), Psychology of Risk Perception (Nova Science Publishers, Hauppauge, N.Y. 2010).

${ }^{107}$ Paul Slovic, 'Perception of Risk' (1987) 236 Science 280.

108 ibid.

109 Amos Tversky and Daniel Kahneman, 'Judgment under Uncertainty: Heuristics and Biases' (1974) 185 Science 1124.
} 
making on a daily basis as they ease the cognitive processes. ${ }^{110}$ Simple rules of thumb require less effort and are on average very useful for 'survival' as we derive results relatively quickly. However, it has been shown that individuals systematically err with regard to the probability that an event occurs and with regard to the impact should such an event occur indeed. ${ }^{111}$ What makes decision-making quick on average does have the disadvantage that it contributes to the misperception of risks.

Heuristics include biases towards events we find easy to recall. ${ }^{112}$ Humans tend to estimate the likelihood of an event, e.g. the risk of being held liable, by the ease with which instances or associations can be brought to mind (availability heuristic). ${ }^{113}$ The availability heuristics include, for example, highly publicised causes of death. When asked to judge frequencies of death by accidents or homicides, people tend to overestimate the true frequency of events, whereas the frequency of under-publicised causes of death like diabetes or asthma is underestimated. ${ }^{114}$ Thus, in using well-known shortcuts, humans are more likely to overestimate the probability of events they remember vividly or where they can recall an incidence of occurrence. ${ }^{115}$ These signals may stem from misreporting in the press and sensation-seeking news stories about incidents and court proceedings in the context of volunteering and altruistic activity. The more sensational an item appears to be, the more likely it is that it will be reported in the media which, in turn, makes it more likely that the frequency of occurrence is overestimated. Research shows that people's fears are also linked to unfavourable media coverage. ${ }^{116}$

Although many media outlets truthfully report cases, e.g. Wilkin-Shaw v Fuller ${ }^{17}$ and Cornish Glennroy Blair-Ford v CRS Adventures Ltd, the focus is often on the human tragedy

\footnotetext{
${ }^{110}$ Several heuristics have been identified: representativeness heuristic, availability heuristic, simulation heuristic, anchoring and adjustment, effect heuristic. In this context the availability heuristic (probability determined by the ease with which examples come to mind) is most likely to be relevant.

${ }^{111}$ Amos Tversky and Daniel Kahneman, 'Judgment under Uncertainty: Heuristics and Biases' (1974) 185

Science 1124.

112 Tversky and Kahneman (n 109) 208.

${ }^{113}$ Ibid.

${ }^{114}$ Paul Slovic and others, 'Risk as Analysis and Risk as Feelings: Some Thoughts about Affect, Reason, Risk, and Rationality' (2004) 24 Risk Analysis 311, 317.

${ }^{115}$ Amos Tversky and Daniel Kahneman, 'Availibility: A Heuristic for Judging Frequency and Probability' in Daniel Kahneman, Paul Slovic and Amos Tversky (eds), Judgement under uncertainty (Cambridge University Press, Cambridge 1982).

${ }^{116}$ Slovic (n 108) 285.

117 Wilkin-Shaw v Fuller \& Ors (n 85). See, for example, http://www.telegraph.co.uk/news/uknews/law-andorder/9362579/Advice-of-scoutmaster-was-to-blame-for-death-of-teen-on-Ten-Tors-challenge-judge-rules.html (accessed 23 February 2017).
} 
and who to blame for the accident. ${ }^{118}$ In a recent article appearing in the BBC News Magazine, the statement that 'you are taking a theoretical legal risk if you clear the pavement in front of your home' seems to draw particular attention to the potential legal dangers of this ostensible act of good citizenship without indicating that the probability of this legal risk materialising is very low. ${ }^{119}$ Moreover, an article that appeared in the Mail online suggested that: 'there is a good reason, however, why so few of us bother to clear the pavements outside our homes. There remains a deep suspicion that the reward for our efforts might be to end up in a court of law being sued by someone who slipped and fell on any snow, slush or ice that we leave behind.' ${ }^{120}$ The article then proceeds to contradict its hitherto scaremongering tone by suggesting categorically that 'no British homeowner can be sued or fined for leaving the pavement outside his home knee-deep in snow or coated with naturally-formed ice.' In an attempt to balance such reporting, the British government offers advice on snow clearing. It states on its official website that it is 'unlikely that you'll be sued or held responsible if someone is injured on a path or pavement if you've cleared it carefully.' ${ }^{121}$ While we agree that information and education are one remedy against sensational reporting, the Government's message is rather cautiously phrased and may not be a strong enough signal to counterbalance the perception of liability. The phrase 'unlikely' to be sued, for instance, may be insufficient to calm the nerves of a risk-averse population. ${ }^{122}$ This type of language does not pose problems for the trained lawyer who knows the rules, but for the untrained amateur the subtleties of 'unlikely' and other rather defensive phrases are less reassuring. What is more, media reporting appears to signal that there is a liability risk, even when socially beneficial activities are involved. ${ }^{123}$

However, it would be too simplistic to state that news reporting alone influences the perception of risks and, thus, the perception of negligence liability. Accidents work as signals about risks but there is not a straight-forward link between accident reporting and risk

118 Cornish Glennroy Blair-Ford $v \quad$ CRS Adventures Ltd $\quad(\mathrm{n} \quad 85)$. See http://www.telegraph.co.uk/education/educationnews/9472311/Teacher-left-paralysed-after-school-trip-losesHigh-Court-claim.html (accessed 23 February 2017).

119 http://news.bbc.co.uk/1/hi/8443745.stm (accessed 23 February 2017).

120 http://www.dailymail.co.uk/news/article-2098008/Should-fined-dont-clear-snow-path-outside-house.html. (accessed 23 February 2017).

${ }^{121} \mathrm{https}$ ://www.gov.uk/clear-snow-road-path-cycleway (accessed 23 February 2017).

${ }_{122}$ For decision-making and risk, see Tversky and Kahneman (n 115). Individuals tend to be risk averse, Daniel Kahneman and Amos Tversky, 'Prospect Theory, An Analysis of Decision under Risk' (1979) 47 Econometrica 263.

${ }^{123}$ See, for example, the misleading headline of an article in the Leicester Mercury that is actually very informative on snow-clearing: https://www.leicestermercury.co.uk/news/uk-world-news/law-clearing-snow-icefootpaths-909444 (accessed 26 March 2018). 
perception. High profile accidents can work as (false) signals about risks because they are not necessarily related to the number of fatalities. For example, in the Three Mile Island accident, where radioactive material was released into the environment in Pennsylvania (USA) in 1979, not a single person died as an immediate consequence but it was received as a signal about the dangers of nuclear power. It has been shown that the signal potential is related to the characteristics of the hazard. ${ }^{124}$ 'Unknown' risks and 'dread risk' ${ }^{125}$ are likely to increase the perception that even a small accident is the 'harbinger of further and possibly catastrophic mishaps. ${ }^{126}$ Applying these lessons to the perception of negligence liability, there may well be a good argument that people fear legal matters. ${ }^{127}$ Sensationalist news reporting in the context of health and safety as well as negligence liability may work as strong signals of a (mere theoretical) risk of liability.

The perception of risk must also be looked at in the context of perceived benefits. This is particularly important with regard to altruistic acts. We characterised altruistic acts as actions for which the intervener does not receive a direct benefit in exchange. There is likely to be a benefit in a sense that people feel better when they give, but this may be a benefit too small to outweigh misperceived risks. Furthermore, Alhakami and Slovic demonstrated that there is an inverse relationship between perceived risks and perceived benefits. ${ }^{128}$ Activities that are judged high in risk tend to be judged low in benefit. It was found that people tend to confound benefits and risks in their minds, even if it was, for example, a high benefit and high risk activity. If people affix a high(er) risk of liability to altruistic acts, this may also diminish their sense of benefit that is associated with a particular activity. In other words, the misperception of liability risks could potentially lower the perceived benefits and, thus, diminish the willingness to help. ${ }^{129}$

\subsection{Is change required?}

\footnotetext{
124 Slovic (n 108) at 283.

${ }^{125}$ Unknown risks are risks that are not being observable, new to the people exposed or where there is little knowledge about the risk. The dread factor includes criteria such as uncontrollability of risk, possibility of a global catastrophe, high risk to future generations, risks not being easily reduced and involuntariness.

${ }^{126}$ Slovic (n 108) 283-284.

${ }^{127}$ It is not clear whether people are afraid of legal entanglement to the extent that it becomes a dread risk.

${ }^{128}$ Ali S Alhakami and Paul Slovic, 'A Psychological Study of the Inverse Relationship Between Perceived Risk and Perceived Benefit' [1994] 14 Risk Analysis 1085.

${ }^{129}$ There is some evidence that people are willing to hurt themselves when helping, Christopher Y. Olivola, Eldar Shafir, 'The Martyrdom Effect: When Pain and Effort Increase Prosocial Contributions' (2013) 26 (1) Behavioral Decision Making 91. The decision to incur pain may be context-dependant.
} 
There are few reasons to fear that a helper or Good Samaritan will be held liable for negligence under English law. In the previous subsection, we have shown that there is evidence that the public predictably over- or underestimates risks. This is likely to apply to the risk of negligence liability too. As a consequence of overestimating the probability of liability, individuals may reduce their efforts to help. ${ }^{130}$ For lawyers, the intuitive reaction to a legal problem is to call for a change. In this instance, rule changes may not have the desired effect because it is the perception of the rules that causes the problem.

The first and rather trivial conclusion is to consider the public's attitude: ${ }^{131}$ The general public is not aware of negligence rules or able to tell that the law is lenient in cases of altruism. This means providing better guidance. That there is guidance available on altruistic acts does not mean that it is helpful. If, for example, we look at the area that has determined the title of this paper, we find that the Government's Guidance on snow clearing is lacking. ${ }^{132}$ The government's webpage is meant to encourage the general public to clear snow. However, it addresses the issue of liability first and does so in a negative way. The introductory paragraph reads: "You can clear snow and ice from pavements yourself. It's unlikely that you'll be sued or held responsible if someone is injured on a path or pavement if you've cleared it carefully." The phrase 'unlikely' is vague and the problem is that people tend to interpret ambiguous probabilities corresponding to their existing beliefs. ${ }^{133}$ Those who heard about liability for injuries sustained on cleared footpaths (although we have not been able to identify a case), or those of us who are generally risk averse, will overestimate the remaining risk and are likely to be discouraged from keeping paths clear from snow. Lord Hodgson referred to this as guidance being phrased in negative terms. ${ }^{134}$ The lesson for the law is to communicate positively or express probabilities more precisely, but this is sometimes a difficult position for lawyers to adopt as they are often inclined to formulate advice cautiously. ${ }^{135}$

\footnotetext{
${ }^{130}$ Another potential consequence of misconceived risks is that individuals and organisations are likely to spend more on risk assessments and insurance. For the value of risk assessment in recent court proceedings, see Reynolds v Strutt \& Parker LLP (n 85); Wilkin-Shaw v Fuller \& Ors (n 75); Cornish Glennroy Blair-Ford v CRS Adventures Ltd (n 75).

${ }^{131}$ In the context of risk perception, see Slovic (n 108) 285.

$132 \mathrm{https}$ //www.gov.uk/clear-snow-road-path-cycleway.

${ }^{133}$ See, for example, Craig R Fox, Amos Tversky, 'A Belief-Based Account of Decision Under Uncertainty' (1998) 44(7) Management Science 879.

${ }^{134}$ Hodgson of Astley Abbotts (n 3) 4.

${ }^{135}$ A good example of those difficulties is that the authors of this article could not agree on how the Government's advice on snow-clearing could be phrased more positively.
} 
Another issue is how to counter sensational reporting that influences perceptions of liability. The Social Action, Responsibility and Heroism Act 2015 (SARAH) was an attempt to reassure volunteers that the courts will consider the context of their actions in the event that they are sued for negligence or breach of statutory duty. ${ }^{136}$ In a research paper underpinning the SARAH Bill, it was pointed out that the general public fears liability in situations where there is no or little risk of negligence liability. ${ }^{137}$ Thus, one of the aims of SARAH ought to have been to redress that fear. However, the message the Act seeks to convey may not have reached the correct audience. The Act is certainly well intentioned insofar as it seeks to reduce the scope for liability of volunteers, but the difficulty is that the only people who generally read statutes are lawyers and judges. Thus, any influence it may have in terms of remedying unfounded fears of liability from the public may be severely limited, especially if it is unsupported by any sustained public information campaign designed to reach a wider target audience. As a standalone intervention, the placating effect of any legislation will be meaningless unless the key message of only a remote chance of liability can be simplified and conveyed to the general public in an easily decipherable format. This may be easier said than done though as SARAH, like many other statutes, uses open language that requires interpretation. If the intended purpose was to educate and reassure volunteers, it may not be suitable to achieve that objective. The language is neither clear enough to be understood by non-lawyers, ${ }^{138}$ nor is it positively phrased. ${ }^{139}$ It seems to have created more 'shades of grey' instead of the desired certainty.

If the UK Government wishes to send a much stronger message to encourage acts of altruism in society, it could consider introducing total immunity from negligence liability for Good Samaritans and volunteers, or a higher threshold such as gross negligence or reckless disregard. ${ }^{140} \mathrm{~A}$ similar position exists in the USA, where volunteers are protected from negligence lawsuits unless they act wilfully or recklessly. ${ }^{141}$ The legal benefits of volunteer

\footnotetext{
${ }^{136}$ Catherine Fairbairn and John Woodhouse, 'Social Action, Responsibility and Heroism Bill, Bill No 9 of $2014-$ 15' (2014) Research paper; UK Government, 'Social Action, Responsibility and Heroism Bill, Fact Sheet' (05 August 2016) https://www.gov.uk/government/uploads/system/uploads/attachment_data/file/318839/sarah-billfact-sheet.pdf (accessed 05 August 2016).

${ }^{137}$ Fairbairn and Woodhouse (n 136).

${ }^{138}$ What does 'must have regard to' mean? What is a 'predominantly responsible approach'? When is someone acting for the 'benefit of society or parts thereof'?

${ }^{139}$ Critics argue that SARAH is also a questionable use of legislative resources. See Lord Pannick HL Deb 04 November 2013, vol 756, col 1563.

${ }^{140}$ E.g. Section 680 of the German Civil Code limits tort liability of rescuers to intent or gross negligence if there was an imminent danger for the life or health of the injured person.

${ }^{141}$ See 42 U.S.C. 14501-05. Immunity does not extend to harm caused by a volunteer operating a motor vehicle.
} 
immunity laws are unclear, but, as Horwitz and others have pointed out, immunity laws may well be able to increase the perceived safety from legal actions. ${ }^{142}$ The authors found that the law is likely to affect individuals' decisions to volunteer, and that those who live in jurisdictions with immunity laws (in the USA) are more likely to volunteer than those who live in nonimmunity States. ${ }^{143}$ This perhaps suggests that the general public's perception changes, depending on the messages that are sent. To this end, introducing immunity for voluntary acts, coupled with effective communication of that legal position to the public, could cause a greater willingness among society to act altruistically ${ }^{144}$ It is doubtful that there will be immunity legislation for volunteers in the UK any time soon. However, as we have identified, the manner in which English law has developed means that immunity rules are not, in actual fact, necessary to achieve to goal of encouraging people to help. What is needed is a more effective public information campaign to set out that there is only a slight risk of liability and, if conducted appropriately, this could have the same beneficial effect as guaranteeing immunity.

The US experience as well as the available evidence demonstrate that for the general public the perception of law matters and often exaggerates real threat from liability. Hence, the challenge for lawyers and policy makers is to communicate more effectively the actual position that the law adopts. The Government's website on snow clearing is a good starting point, but much more has to be done to make volunteers understand that they will not be liable if they use common sense and take reasonable care. Lord Young called for more clarity in his report on "Common Sense Common Safety": "Clarify (through legislation if necessary) that people will not be held liable for any consequences due to well-intentioned voluntary acts on their part." 145

\section{Conclusions}

In this article we have sought to illustrate that, while a risk of liability does exist in respect of volunteers, the chance of that risk ever materialising is remote, and perhaps overestimated. It is likely that a helper who accidently causes harm owes a duty of care because she may have

\footnotetext{
${ }^{142}$ Horwitz, Jill R. Mead, Joseph, 'Letting Good Deeds Go Unpunished: Volunteer Immunity Laws and Tort Deterrence' (2009) 6 Journal of Empirical Legal Studies 585.

143 Ibid.

144 Ibid at 627.

${ }^{145}$ Young of Graffham, ‘Common Sense Common Safety’ (2010) 15.
} 
either created a new risk or assumed responsibility. However, as we have argued above, the courts are unlikely to find a breach of duty due to a more forgiving standard of care applied to helpers. The benefit of altruistic actions and the desire to incentives volunteering will normally outweigh factors supporting a breach of duty. ${ }^{146}$ Both the lack of actual cases squarely on point, and the way in which judges have approached the assessment of breach, support this contention. The threshold for imposing liability has, rightly, been set at a high level and the upshot is that, in most cases, it is highly unlikely that anyone who provides help or assistance will be liable to pay compensation in negligence where they have caused harm as a result of their voluntary actions.

The problem is that the sympathetic approach that has been adopted by judges in England in respect of volunteers may be largely unrecognised by members of society. The majority of people, quite understandably, will have very little awareness of how the substantive legal rules operate and the fact that they are weighted heavily towards safeguarding Good Samaritan behaviour. It follows that there may still be a problem with misleading perceptions of the law and a skewed understanding of how likely it is to be held liable for altruistic acts that do not go according to plan. This, in turn, may be having a negative impact upon people's enthusiasm to provide voluntary help to others.

People may sometimes fall into the trap of thinking that there is a greater risk of being sued than is actually the case. We have suggested that this view can be mitigated against, at least to an extent, by effective signalling and communication that more accurately reflects the law and informs about realistic probabilities of liability. Both the Compensation Act 2006 and SARAH attempt to address how voluntary acts ought to be assessed by judges when considering the appropriate standard of care, but whether or not these provisions go far enough is subject to debate. Misleading information portrayed by certain sections of the media may be a culprit in contributing towards bystander apathy and thus we suggest it is incumbent on the government to provide a higher degree of clarity in communication the law. This could be achieved by ensuring that there is a greater emphasis placed on education and enhanced guidance to inform people more comprehensively about the true nature of the legal position in regard to offering assistance, which may be one way of tempering some of the exaggerated scenarios that surround the threat of liability. The impact of this may hopefully contribute

\footnotetext{
${ }^{146}$ Our analysis does not deal with issues of causation and remoteness and we have not addressed potential questions regarding the defences available against an action in negligence, particularly contributory negligence and volenti non fit injuria.
} 
towards a greater willingness amongst people in society to offer help to their fellow neighbours on a more frequent basis. 